\title{
Intralingual Errors in Iraqi EFL Learner's Writings
}

\author{
Lina Lafta Jassim* \\ College of Art, University of ThiQar, Iraq
}

*Corresponding Author: Lina Lafta Jassim, College of Art, University of ThiQar, Iraq,

\begin{abstract}
The present study tries to indicate the sources of intralingual errors in Iraqi EFL learner's writings at the University of Basrah. When the educators recognize these sources or reasons, they can effortlessly assist their learners to overcome the difficulties in writing in English. The sample of this study consists of fifty-two students in the third year from the translation dept., College of Arts, University of Basrah. There are two hypotheses for this study: First, most learners fall in false concept hypothesized errors. Second, the learners have problems in using appropriate tense with context. The results of this study show that intralingual errors occur as a result of the difficulty of some syntactic structures in the English language.
\end{abstract}

KEYWORDS: intralingual, errors, English, writing, sources

\section{INTRODUCTION}

The most complex skill in English is writing. Therefore, most Iraqi learners commit errors in writing in a target language. In helping the learners to successfully learn writing skills, the error analysis, and the understanding of the reasons are necessary. The process of writing requires linguistic synthesis and cognitive analysis. It is difficult to write in a target language because it demands a lot of time and effort. Many related studies show that EFL students make errors in their writing in the target language(Alan,2015). For Richards (1971), intralingual errors reflect the difficulty or complication of English structures and misunderstanding of grammatical rules by EFL learners. The main reasons that lead the learners to fall in these errors are inadequate learning and weakness in teaching. According to Thommasat (2014), The factors that lead EFL learners to fall in intralingual errors are graphic/phonic resemblance, false-concept hypothesized, overgeneralization, ignorance of rule application, incomplete application of rules, and exploiting redundancy.

\section{INTRALINGUAL ERRORS}

These errors occur as result of faulty or limited learning of the English language instead of language transfer (Alan,2015) .For Abu Naba'h (2019), these types of errors occur as a result of EFL students ' attempt to structure concepts and assumptions about the English language from their partial knowledge about it. The intralingual errors are common occurred in the EFL learners' writings and these errors are often analyzed to recognize what strategies types which the EFL students use in their writings. Intralingual errors are: overgeneralization, simplification, communication- based and induced errors.

Laufer (1986) uses the term "synophone", in his study, to refer to intralingual errors. According to ( Abu Naba'h , 2019), intralingual errors occur as a result of the confusion of language learner experiences when confronting patterns within the structure of a newly acquired language, irrespective of how the target language patterns might contrast with the learner's mother tongue. For example, the learner may be thinking of 'take' but he or she confused it with 'talk'.

There has been interest in studies which are associated with writing skills in current years, as such skills are very important in our academic studies as well as outside academic fields (Alan,2015).Thus, it is clear that the process of writing is important to structure our relations with other people and organizes our understanding for the world .

\subsection{Related Studies}

Al-Tamimi (2006) examined forty samples of essays produced by Pakistan EFL students. The analysis of errors demonstrated that the most errors were from intralingual sources. Though there were few errors committed from the interference of the learners' native language. Alen (2015) 
examined errors committed by the students at the University of Medicine in Thailand. His study reported that fife types of errors committed by the students. The findings of Alen's study also revealed the errors produced mostly by intralingual sources are: overgeneralization, building of false concepts, incomplete rule application, and omission. The mother language interference was included in a small proportion. In spite of the fact that many previous studies showed insights about the probable errors committed by EFL students' essays, educators face difficulties in teaching English writing to their students. The challenge in writing in the target language still found. Consequently, the errors analysis in writing are nonstop and needed to be conducted continuously.

\subsection{False Concept Hypothesized}

According to Alen(2015), this error occurs when the student misunderstands a particular rule. In this way, he formed a hypothesis of a target language item and put it into his /her writing. Al-Tamimi (2006: 44) indicates that this type of error can be defined as "something due to poor gradation teaching item". The learners might form hypotheses about some grammatical rules of the L2. For example, an L2 learner might interpret using the forms 'was or did' wrongly when he/she thinks that these forms are markers of the past tenses; therefore, he/she produces utterances such as 'one day it happened' or 'she has finished the homework' (Richards,1970). The errors that result from false concepts hypothesized can be attributed to classroom presentation, particularly when extreme attention is paid to differences at the realistic English expense. Arch forms and double marking are also examples of errors that might be caused by 'faulty comprehension of rule distinctions'(ibid).

\subsection{Incomplete Rule Application}

This error occurred when the learner failed to learn complex structures. That is why he prefers simple forms and constructions instead of using complicated ones (Olasehinde,2019).For Al-Khresheh (2016), incomplete application of rules may be also called as failure to achieve complete knowledge of the target language. It occurs when a learner finds that he/she can communicate successfully by using simple grammatical rules rather than more difficult ones. Touchie (1986) used the term " simplification" to refer to similar errors. Alen(2015)identifies that it is opposite to overgeneralization (see the following section)and exemplifies this deviancy of subject and verb "be" found in the sentence:

-Nobody knew where* was Barbie. (Barbie was)

This error comes from the writer using an incomplete rule of interrogative information. That is, the writer successes in using wh-question 'where' but he failed to convert the subject "Barbie" and the verb 'was' to farm a complete declarative statement. (Sompong, 2014)

- you speak English?

-What you do in the evening?

In the examples above, the learners used statement words instead of question one in the former sentence. However, they added only question word at the beginning of the latter sentence(Tram, 2010:29).

\subsection{Overgeneralization}

According to Richards (1974), this error deals with redundancy reduction. It occurs because of the learners' assuming that a rule or pattern, in English, operates without exception (Scovel, 2001).In other words, this error may be the result of using a deviant structure on the basis of learners' experience of other structures in English. It may be the result of the learner reducing his linguistic burden. Lim (2010) indicates that overgeneralization is intralingual in nature because of being as a form of grammatical or morphological simplification.

overgeneralization may be a result of the learners' tendency to use previous strategies in a new situation. Some of these strategies are a benefit but others will be misleading, e.g., omitting -sending after verbs of singular third persons as ' He *read a novel' (Tram, 2010).

It involves the creation of one deviant structure instead of two regular structures, (Hasyim:2002).That is, the learner uses one member of a set of forms also in situations when the other members must be used. This usually leads to overuse of one form and underuse of the others. Well, known candidates 
for overgeneralization are pairs as other/another, much/some/many, etc. (Lim, 2010). It is opposite to hypercorrection (See more details in Hypercorrection section).

For examples :

-He *want. (wants)

In the above example, there is omission of 3rd person singular .

-Does she can dance?

This example reflects that the of learner overgeneralizes the use of auxiliary verbs in questions. In addition, learners may use *'drinked 'and *'goed' as the past tense of 'drank' and 'go'. For Olasehinde (2020), the main causes of overgeneralization and false concept hypothized errors are: ignoring exceptions, regularizing the language and simplification the language.

\subsection{Overlooking Co-Occurrence Restrictions}

According to Richards (1974:31), a learner ignores the rule restrictions. That is, the learner is unable to administrate rules to inappropriate situations, for example: having learned the sentence structure 'she arrived at home yesterday' which is absolutely correct, a learner may use this previously acquired grammatical rule in a new situation or he/she might apply it in a situation such as 'she has arrived at home yesterday', which is definitely wrong. Disordering can be a good example of such errors that are caused by ignorance of rule restrictions. These errors occur when the learner doesn't know that certain words go together with certain complements, prepositions, etc. That is, these errors may be a result of learners' ignorance of rule restrictions and incomplete learning. It is also named "oxer-laboration". For example:

-I would enjoy* to play (playing)

For Sompong (2014), above example,' enjoy' ought to be followed by a gerundial complement. Many EFL students make use of the previous acquired rules in new contexts where they do not apply. Misunderstanding of concepts and weakness of teaching are the reasons which lead the learners to fall of these errors. For example, the learner may use the preposition 'about' with the verb 'discuss' .At the same time, they see that it is possible to use this preposition with the verbal verbs as' like', 'tell' and 'speak' .For example, 'we talk about it leads' to 'we discuss about it ', 'he tells him to do it ' to 'he make him to do it' and so on (Olasehinde,2019).

\subsection{Hypercorrection (monitor overuse/ induced errors)}

These errors form the learner's insistence in applying his/her knowledge of certain rules to other information (kaweera: 2013).In other words, these errors form from the learner's over cautious and strict observance of rules. (Sompong, 2014). As Alen (2015) argues that results from the students over-monitoring the target language output".

- I am a second *years English major student. (year)(Kaweera: 2013).

In above example, the writer may wrongly assume that the phrase 'second years' must be in a plural form. This, its turn, leads him or her to fall in error.

\subsection{Exploiting Redundancy}

It refers to the use of words or phrases which add nothing to the overall meaning of the sentence (Kaweera, 2013:14). For example:

-I was happy to get a $*$ free gift.(I was happy to get a gift)

-I have be here ,I *always miss my family .(I have be here, I miss my family

\section{Method ANd Procedures}

A quantitative approach was used to conduct this study. Fifty-two students in the third year from translation dept., College of Arts, University of Basrah, of academic year (2019/2020) were selected randomly to perform the test and to gather the data of this study. The data for this study was gathered from the subjects' response to the test. The test comprised a closed question: Twelve Arabic sentences from contrastive analysis and error analysis by Kershavarz (2018) were given to the subject to convert to English. The twelve sentences were: 
1-He smokes a lot of cigarette.

2- There are many fish in the lake.

3-I think both of them are important.

4- The main food in our country is rice.

5-This is the man who always breaks his promise.

6-I have two animals. These are cat and dogs.

7-I was a second *years student, When I was in the nineteen* years old.

8- I am afraid of dogs.

9- I enjoy learning English language.

10-When the responsibility increases, students cannot perform well.

11-I do not have many friends.

12- Reading English novel makes him improve the language.

Ellis (2018) and Hubbard et al.(2020) give useful advice with examples of how to identify and analyze the errors of learners. The first step requires the selection of a corpus of language. The second step is identifying errors. Then, the errors are classified. The last step demands an explanation of different types of errors.

\subsection{Presentation of Results}

Intralingual errors were identified and classified according to their possible sources. It is important to mention that some sentences are easily understood by native English speakers but they clearly deviate from academic writing.

Table1. Frequency of Intralingual Errors in Iraqi EFL Learners' Writings

\begin{tabular}{|l|l|l|l|}
\hline No. & Type of Error & Frequency & Percentage \\
\hline 1 & False concept hypothesis & 78 & 36.6 \\
\hline 2 & Overlooking co-occurrence restrictions: & 55 & 23.8 \\
\hline 3 & Phoniclgraphic resemblance & 50 & 21.6 \\
\hline 4 & Hypercorrection & 21 & 9.09 \\
\hline 5 & Overgeneralization & 14 & 6.06 \\
\hline 6 & Incomplete rule applications. & 13 & 5.6 \\
\hline 7 & Exploiting redundancy & 0 & 0 \\
\hline & Total & 231 & 100 \\
\hline
\end{tabular}

Table above shows that false concept hypothesis errors were the most common types of intralingual errors made by subjects. That is, (35.9) of the total number of errors. This proves that the first hypothesis of the present study, which indicates that most EFL learners fall in false concept hypothesized errors, is true. Intralingual errors took the form of overlooking restrictions with $23.8 \%$, phonic /graphic resemblance with $21.6 \%$, hypercorrection $9.10 \%$, overgeneralization 6.06 and incomplete rule application 5.6\%. However, the exploiting of redundancy errors weren't committed in the subjects' writings.

\subsection{False Concept Hypothesis Errors}

1. There *was *some fish in the lake.

2. I think both of them *is important.

3. I am afraid of $*$ dog.

4. I have two types of animals. *Its*is a cat and a dog.

5. I* am think that both of them are important.

6. He* is *smoke cigarette a lot.

7. ...who *is always breaks his promise. 
8. When the responsibility *was increased....

9. The rice is *original food in our country.

In sentence 1,the subject misanalyses that the word "fish" is single, so he /she uses "was" instead of 'are' and 'some' instead of 'many'. In sentence 2 , the subject forms a hypothesis of a TL item and put it into their writing. The subject may hypothesize that 'both of them' can be used to refer to single thing. That is why, he/she uses 'is' instead of the word "are". He/she use 'dog' instead of the word 'dogs' in sentence 3 .The wrong use of 'its' instead of ' their ' in sentence 4 ,which reflects the subjects' wrong concept of the TL rules. That is, he/she hypothesizes that 'its' is a plural form of the pronoun 'it' .That is why, he /she adds's' to the end of ' it' to make plural form instead of saying 'there are'. From (5-8), the subjects seem unable to comprehend the distinction in the TL .The subjects think that 'is' as present tense marker in 5, 6 and 7 sentences. However, they use past tense in sentence 8.In sentence 9 , the subject may have wrongly comprehension of the distinction between the adjective 'original' and 'main'. That is why, the subject hypothesizes that 'original' and ' main' can be used interchangeably.

\subsection{Overlooking Co-occurrence Restrictions}

11. I enjoy* to learn English language.

12. There are many $*$ fishes in the lake.

13. I *thought both of them are important.

14. I am afraid *from dogs.

In sentence 11, the subject ignores the fact that the verb 'enjoy' should be followed by a gerundial complement. The subject thinks that 'fishes' is plural form of 'fish' in sentence 12. In this way, he /she fails to know the restriction of the target language structures. Look to sentence 14, The subjects seem to have problems in using appropriate preposition with context, so they misuse the preposition 'from' with the verb 'afraid ' instead of 'of'.

\subsection{Incomplete Rule Applications}

15. I *haven't many friends.

16. I* scared* dogs.

17.* our country, rice is the main food.

18. When responsibility *increased students cannot perform well.

19. I *am a second year student, When I was in the nineteen years old.

Despite of using 'don't have' to say negation, the subject omits it and applies the rule as 'haven't' in 15 sentence .In 16, deposit of saying 'I am scared of dogs ',the subject omits the auxiliary verb 'am' and necessary preposition 'of' .In 17,there are omission of the preposition 'in' at the beginning of sentence and the article 'the ' before 'rice' .In 18 and 19 sentences, there is misuse of tenses , I.e., the subjects use of 'increased' instead of 'increases' and ' am' instead of 'was'. They have difficulty in using tenses harmonically in the main clause and subordinate clause. This proves that the second hypothesis of this study, which emphasizes that learners have problems in using appreciate tense with context, is true.

\subsection{Overgeneralization}

20. I don't have* much friends.

21. I *does not have many friends.

22. The man* that always breaks his promise.

23. Students cannot perform *good.

24. He *smoke cigarette a lot.

25. When the responsibility* increase, students can't perform * good

In sentence 20, the word 'much' is used instead of 'many'. However, there is misusing of subject-verb agreement in sentence 21 . That is, the subject overgeneralizes the use of third person singular "'he',' 
she', 'it' " with the first person 'I' .Thus, he/she use the singular verb 'does' with 'I' .However, they used 'that' to the exclusion of 'who' which cannot be used as sentence (22).In sentences 23 and 24 ', 'good' is used instead of 'well' .Also there is omission of third person singular '-s' in 'smoke' and 'increase' caused by overgeneralization in 24 and 25 sentences .

\subsection{Phonic /Graphic Resemblance.}

26. I think both of them are* improtant. (important)

27. When the *respocibilty increases the student .....(responsibility)

28. I would *injoy learning. (enjoy)

29. This is the man who always* braeks.. (breaks)

In sentences (26-29), the students were thinking of 'important' but they confused it with 'improtant', 'responsibility' with 'responcibility', 'enjoy' with 'injoy', 'breaks' with 'braeks' and 'solve' with 'desolve'.

\subsection{Hypercorrection}

30. I was a second *years student. When I was in the nineteen *year old.

31. When I was in the nineteen years old. I was a second *stages student.

32. Reading English novel makes him *improves the language.

In sentences 30 and 31, the subjects wrongly assumed that the phrases 'second years' and 'second stages' should be in a plural form. That is why, there is needed to put the noun ending 's' .Also the subject misuses the phrase 'nineteen year' instead of saying 'nineteen years' in 30 . In sentence 23, the subject seems to be confused with the rule of adding 's' for the agreement on subject-verb form the word 'him' as a third person singular and the verb 'improves'.

\section{FINDING AND DISCUSSION}

The findings of the study show that many EFL learners' intralingual errors are due to false concept hypothesized, unawareness of rule restrictions and phonic or graphic resemblance. Beside our analysis, it can be assumed that the learners are unable to use appropriate tenses with context in their writings. Beside, in constructing complex sentences, they have difficulties in using tenses harmonically in main clause and subordinate clause. For example, "I am a second year student, When I was in the nineteen years old." .Because there is a relationship between grammar and meaning, the incorrect grammatical structures can affect the meaning they want to convey. In the present study, most of the learners are not able to distinguish between some confusing items such as "main" and "original". They also make errors in using preposition since they do not master the use of preposition. For example, 'I am afraid from dogs'.

To remedy the learners' problems above, the present study suggests some solutions .As the learners have problems in using appropriate tense with the context, the grammatical rules must be introduced and explained clearly in the context, for example, encouraging of learners to find the rules by themselves in the text, despite of asking the learners to learn the rules by heart. This can help to overcome the difficulties of foreign language learning. Encouraging the learners to write stories or assays about their topics, this helps the learners in practicing the grammatical rules by themselves. In this way, the role of teachers appears, when they use direct or indirect corrective feedback and remedial teaching programmed (Simargool 2008:99).

\section{CONCLUSION}

EFL learners have learned a target language since they were in primary schools. Nevertheless, their English competence, especially writing skills, is still unsatisfied. Analysis of errors has been broadly used as a way to understand how the skill of writing is learned by EFL learners. The results of this study show the significance of understanding the reasons or sources of intralingual errors in learner's writing. When teachers recognize these reasons, they can easily help their learners to overcome the difficulties of English learning. The results have gone some way towards encouraging the teachers in understanding and identification of the types of intralingual errors. Because this study involves both male and female, the results can be considered as more generalizable. 


\section{REFERENCES}

[1] AbiSamra, N. (2003). An Analysis of Errors in Arabic Speakers' English Writings. The American University of Beirut. Available on: http://nadabs.tripod.com/languageacq -erroranalysis.html

[2] Abu Naba'h, A. (2019).Lexical Errors Made by In-Service English language Teachers in Jordan. Damascus University Journal, Vol. 27, No (1+2). Available on: https://www.google.iq/url?sa=t\&source= web\&rct=j\&url=http://www damascusuniversity.edu.sy/mag/edu/images/stories/4975.pdf\&ved

[3] Al-Khresheh, M.H.(2016).A Review Study of Error Analysis Theory. International Journal of Humanities and Social Science Research, 2016, vol (2), 49-59.

[4] Available on: http://www.lifescienceglobal.com/pms/index.php/ijhssr/article/ view/3722/2184

[5] Al-Tamimi, A. (2006). An investigation of interlingual and intralingual interference in the acquisition of English present tenses by Yemeni learners. Unpublished MA Thesis, UniversitiSains Malaysia, Penang, Malaysia.

[6] Corder, S. (1967).The significance of learners' errors. International Review of Applied Linguistics, 5(4), 161-169.

[7] Ellis, R. (2019).SLA Research and Language Teaching. Oxford :Oxford University Press.

[8] Hasyim,S. ( 2002). Error Analysis in the Teaching of English. Journal'Kata'(1(42-50). Available on:

[9] http: //puslit.petra.ac.id/journal/letters

[10] Hubbard, P; Jones, H.; Thorton, B and Wheeler, R. (2020) .A Training Course for TEFL. Oxford: Oxford University Press.

[11] James, C. (1998). Errors in language learning and use: Exploring Error Analysis. London: Longman.

[12] Jiang, W. (2009). Acquisition of Word Order in Chinese a Foreign Language. Mouton de Gruyter: Germany. Available on: http://dx.doi.org/10.1515/9783110216196.

[13] Kaweera, C.(2013) Writing Error: A Review of Interlingual and Intralingual Interference in EFL Context School of Liberal, Arts Canadian Center of Science and Education, University of Phayao: Thailand; Vol. 6, No. 7.Available on: https://www.google.iq/search?biw=1280\&bih=752\&ei=FKAUWMXXI8Sla7LOllA\&q=kaweera+2013+er ror+analysis\&oq=k.

[14] Keshavarz, M. H. (2018). Contrastive analysis and error analysis. Tehran: Rahnama Publication.

[15] Laufer, B. (1986). Possible changes in attitude towards vocabulary acquisition research. International Review of Applied Linguistics. 24 (1) 69-75.

[16] Lim. M, H. (2010). Interference in the acquisition of the present perfect continuous: implications of a grammaticality judgment test. The Open Applied Linguistics Journal, 2010, 3, 24-37.

[17] Available on :http://dx.doi.org/10.2174/1874913501003010024

[18] Olasehinde, M. O. (2019).Error analysis and remedial pedagogy. In Babatunde S. T. and D. Richards, J. C. (1971). A non-contrastive approach to error analysis. English language teaching journal, 25, 204-219. Available on: http://dx.doi.org/10.1093/elt/XXV.3.204

[19] --------(2020). A Non-Contrastive Approach to Error Analysis. Richards, J. (Ed.). Error analysis: Perspectives on Second Language Acquisition. 172-188. Essex: Longman.

[20] Scovel, T. (2001). Learning new languages: A guide to second language acquisition. Boston, MA: Heinle\&Heinle.

[21] Simargool, N. (2008). Interlanguage passive construction. Journal of Pan-Pacific Association of Applied Linguistics, 12,(1), pp.97-119

[22] Sompong, M, (2014).Error Analysis. Thammasat Review, Vol.16, No.2, pp.109-127.

[23] Available on: https://www.google.iq/search? biw=1280\&bih=752\&ei=654fWIj1CaTLgAasiJ-

[24] Alan (2015). Learning English - Pronunciation Tips. Available on: www.bbc.co.uk/worldservice/learnin genglish/multimedia/pron/progs/ prog1.

[25] Touchie, H.Y. (1986).Second Language Learning Errors Their Types Causes, And Treatment jolt journal, volume 8 , no. $1,55-112$

[26] Available on: http://documents.mx/documents/common written-errors-committed-by-first-year-studentsat-felte-hulis

[27] Jassim, L. L.(2015). Analysis of Semantic Errors in Iraqi EFL Learners\&\#39; writings. The Journal of University of Thi-Qar,11(4):184-162.

[28] Jassim, L. L.(2016). Investigation of Sequential Progression Topics in Iraqi EFL Students\&\#39; Writing, The Journal of University of Thi-Qar, 10(3):47-63. 
[29] Jassim, L. L., \&Dzakiria, H.(2019). The Effect of Utilizing Mobile on Developing English Writing Skill. Opción,(34),(19).(PP:2128-21437)

[30] Jassim, L. L., \&Dzakiria, H. (2019). Effective Use of Facebook in Improving English Communication Skills: A Conceptual Paper. Dirasat, Human and Social Sciences, 46(2 Supplement 2).

\section{APPENDIX}

Q / Translate the following sentences into English:

$$
\begin{aligned}
& \text { يدخن الكثير من السجائر. } 1 . \\
& \text { هناك العديد مناسماك في البحيرة. } \\
& \text { اعتقد أن كليهما مهم. } 3 \\
& \text { 4.ان الرز هو الطعام الرئيس في بلدي. } \\
& \text { هذا الرجل دائماً لايوفي بو عده.5 } \\
& \text { 6. لدي نو عان من الحيو انات هما القط و الكلب. } \\
& \text { 7. كنت في المرحلة الثانية عندما كنت في التاسعة عشر عاما. } \\
& \text { 8.اخشى الكلاب. }
\end{aligned}
$$

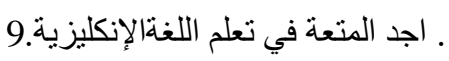

$$
\begin{aligned}
& \text { لايسنطيع الطلاب ان يؤدوا جيدا عندما تزداد المسؤولية } 10 . \\
& \text { لا املك الكثير من الأصدقاء. } 11 . \\
& \text { 12. قر اءة الرواية الإنكليزية تجعله يحسن لغته . }
\end{aligned}
$$

\section{AUTHOR'S BIOGRAPHY}

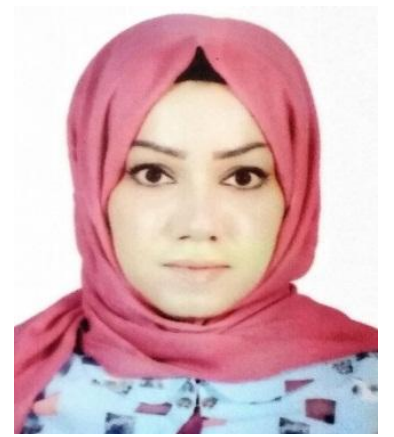

Dr. Lina Lafta Jassim is lecturer of English at College of Arts in the University of Thi-Qar (Iraq ) since 2014. She has five years of experience in teaching English in various colleges and universities. She is an expert in Linguistics, teaching English language skills and Grammar. She has published around twenty research papers in various international journals in the areas of Applied Linguistics, Semantics ,Pragmatics and educational technology. She is also an editorial assistant of Open SAGE journal, a Permanent Reviewer for many publishing groups such as Emerald and Open SAGE which managed Scopus journals 2019 ongoing. A reviewer in International Multidisciplinary Research and Technology (IJMRT) ISSN 2582-7359 , International Journal of English Linguistics Canadian Center of Science and Education and one of editorial team of International Journal of English Language Teaching - Sciedu press. She is also one of editorial broad members for International Journal of Literary Horizon. She has recently been selected for the editor-in-chief position in ISJASSR..

ORCid ID: https://orcid.org/0000-0002-1725-0212

Citation: Lina Lafta Jassim. "Intralingual Errors in Iraqi EFL Learner's Writings" International Journal on Studies in English Language and Literature (IJSELL), vol 8, no. 12, 2020, pp. 33-40. doi: https://doi.org/10.20431/2347-3134.0812003.

Copyright: (1) 2020 Authors. This is an open-access article distributed under the terms of the Creative Commons Attribution License, which permits unrestricted use, distribution, and reproduction in any medium, provided the original author and source are credited. 